\title{
The effect of freeze dried fruit powders on some of the physicochemical properties of the layer cake
}

\section{Dondurularak kurutulmuş meyve tozlarının keklerin bazı fizikokimyasal özellikleri üzerine etkisi}

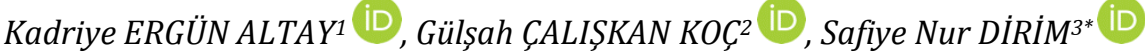 \\ ${ }^{1-3}$ Department of Food Engineering, Engineering Faculty, Ege University, İzmir, Turkey. \\ kadriye_ergun555@hotmail.com,gulsah_caliskan86@hotmail.com,nur.dirim@ege.edu.tr
}

\begin{abstract}
The objective of this research is to observe the effect of the addition of freeze-dried fruit puree powders to cake batter during cake production. The moisture content data pointed out that the addition of fruit powders to the cake batter resulted in a decrease in the moisture content values of the cakes (6.96-34.13\%, $p<0.05)$. The cake with quince powder had the highest volume (90.56-92.78 $\mathrm{mm}$ ) and symmetry index values (6.13-7.00 $\mathrm{mm})$. The vitamin $C$ content (6.17-32.94\%) of the cakes significantly increased with the addition of fruit powder to the cake batter. The sensory evaluation showed that the cake containing pumpkin powder had greater acceptance by the panelists.
\end{abstract}

Keywords: Cake, Kiwi, Pumpkin, Quince, Hardness.
Öz

Bu çalışmanın amacl, dondurarak kurutulmuş meyve tozlarının kek hamurlarına ilavesinin kekler üzerindeki etkilerinin incelenmesidir. Kek hamuruna meyve tozlarının eklenmesiyle, keklerin nem içeriğinde önemli bir düșüs gözlenmiștir (\%6.96-34.13, p<0.05). Ayva tozu içeren kek en yüksek hacim (90.56-92.78 mm) ve simetri indeksi $(6.13-7.00 \mathrm{~mm})$ değerlerine sahiptir. Keklerin $C$ vitamini içeriği (\%6.17-32.94) kek hamuruna meyve tozu ilavesiyle önemli ölçüde artmıştır. Duyusal analiz sonuçlarına göre balkabağı tozu içeren kekler panelistler tarafindan daha çok beğenilmiștir.

Anahtar kelimeler: Kek, Kivi, Balkabağı, Ayva, Sertlik.

\section{Introduction}

Recently, the tendency of consumers for the consumption of functional products made manufacturers produce different and healthier products. At the same time since the consumers prefer ready to use products [1], several food processing companies provide food products with health-enhancing characteristics [2]. Baked products are basic foodstuff which are consumed by the large segment of the society and they are suitable tools for imparting nutrients into people's diet [3] Since the cake is one of the ready food products which is consumed by age groups of society in preference, numerous studies performed for showing the potential enrichment of cake products [1],[2],[4],[5]. The change in the eating habits and the desire of consumers to eat "Natural and functional products" has caused the development of new preservation techniques for the fruits and vegetables. For this reason, nowadays it is very common that, the market offers cleaned, cut and dried vegetable and fruit slices or powders ready for soup, dessert, cake or cookie mixtures as well salad preparations [6]. The addition of these products to cake formulation brings a new aspect of producing a healthy form of food which has been considered as a carbohydrate source. Powder products, with a long-term ambient shelf life and microbiological stability, can be used as natural and easy to use components in food recipes [7]. In the production of powdered fruits and vegetables, it is important to protect their sensitive compounds and for this reason, freeze-drying can be preferred, being a significant method for the conservation of sensitive compounds (vitamins, phenolics, antioxidant compounds, etc.) color, flavor, texture, appearance, and the chemical composition of the foods which compensates for its high operating costs [8],[9]. The objective of this study is to observe the effect of the addition of freezedried fruit powders to cake batter to observe the effects on the cooking quality, cake properties and sensorial properties of the cakes. For this purpose, kiwi, pumpkin, and quince were selected as the fruits which are well known as a rich source of vitamin $\mathrm{C}$, carotenoids, and antioxidants, respectively. As our knowledge, there is no study where the fruit powders are added to the cake formulation. On the other hand, fruit powders are advantages on the items that, easy dosage during formulation, preventing additional moisture due to fruit addition and as an alternative to enrichment of dry cake mixtures.

\section{Material and methods}

\subsection{Raw materials}

The fresh fruits (kiwi, pumpkin, and quince), flour (Sinangil Gıda San. ve Tic. AŞ.), sugar (Keskinkılıç Gıda San. ve Tic. AȘ.), oil (Küçükbay Gıda San. ve Tic. AȘ), eggs (Keskinoğlu Gıda San. ve Tic. ASS), baking powder (Dr-Oetker AS, Izmir, Turkey) and milk (Pınar AȘ. Izmir, Turkey) were purchased from a supermarket in Izmir, Turkey.

\subsection{Methods}

\subsubsection{Freeze-drying of fruit puree}

Kiwi, pumpkin, and quince were peeled, washed and drained and the inedible parts were removed. Fruits were crushed by a blender (Tefal-MB450141, Turkey) and then maltodextrin [MD,

${ }^{*}$ Corresponding author/Yazışılan Yazar 
10-12 Dextrose Equivalence (DE)] (AS CICLC, Turkey) was added as $10 \%$ by weight to the peach puree. Samples $(3 \mathrm{~mm})$ were frozen in an air blast freezer and freeze-dried (13.33 Pa absolute pressure, $-48 \pm 2{ }^{\circ} \mathrm{C}$ condenser temperature, and $+30 \stackrel{\circ}{\circ} \mathrm{C}$ heating plate temperature). The fruit powders were obtained by grinding (Tefal-MB450141, Turkey) of the dried pellets with the diameter of petri size and the powders were stored in the dark at room temperature.

\subsubsection{Preparation of the cakes}

The obtained kiwi, pumpkin, and quince powders were added to the cake formulations with the ratios of 5,10 and $20 \%$ of the total weight of the cake batter (wet basis, wb). For this purpose, the sugar (78.97 g) and eggs (51.53 g) were mixed by using Kitchen Aid, 5K45SS, USA ( 4 min.). The flour ( 49.20 g), baking powder (3.33 g), edible oil (23.45 g) and milk (24.88 g) were added to the sugar and eggs mixture and were whipped (at medium speed for $3 \mathrm{~min}$.) In the final stage, $200 \mathrm{~g}$ of the cake batter was weighed into a greased circular glass baking pan $(14 \mathrm{~cm})$. An electrical oven (Beko, Model OIM22301X, Istanbul, Turkey) was used for the conventional baking (3 min. preheating and $175{ }^{\circ} \mathrm{C}$ for $20 \mathrm{~min}$. baking).

\subsubsection{Physicochemical analysis of fruit powders and cakes}

The moisture content (MC, wet basis, \%) of the powders, and the fortified batter and the cake with the fruit powder were determined according to AOAC [10] and AOAC [11], respectively. The water activity was measured by a water activity $\left(a_{w}\right)$ measurement device (Testo-AG 400, Germany). The color values of samples were measured with a colorimeter (Minolta CR-400, Japan) using the Hunter scale for $L^{*}, a^{*}, b^{*} . L^{*}$ values measure black to white (0 to 100$) ; a^{*}$ values measure redness when positive and greenness when negative, and $b^{*}$ values measure yellowness when positive and blueness when negative.

The weight loss (WL\%) of the cake samples during baking was calculated by using Eq. (1) where W denotes weight (g):

$$
\mathrm{WL}(\%)=\frac{W_{\text {batter }}-W_{\text {cake }}}{W_{\text {batter }}}
$$

The volume (VI), symmetry (SI), and uniformity (UI) indexes were measured after the cakes were cooled for $1 \mathrm{~h}$ at room temperature and then cut into halves from the center. The measurements were performed by using the cake measuring template (AACC method 10-91, [10]).

The vitamin $\mathrm{C}$ contents of the powders, and the fortified batter and the cake were determined according to Hışıl [12]. Rehydrated freeze-dried powders (to initial moisture content) were used prior to the analysis. The indication principle of vitamin $C$ value is based on extraction with $10 \%$ oxalic acid afterward adding the 2,6-dichlorophenolindophenol solution.
The absorbance was measured at $518 \mathrm{~nm}$ (Varian Cary 50 UV/Vis, Australia).

\subsubsection{Hardness}

The hardness values of the cake samples were determined by a Texture Analyser (TA.XT Plus, USA, at room temperature). The cakes were cut into the cylindrical slices $(2.5 \mathrm{~cm}$ in diameter and $2.5 \mathrm{~cm}$ in thickness) and these slices were compressed by using an aluminum circular disc probe $(36 \mathrm{~mm}$ diameter). Crosshead speed, compression distance, and the delay between two bites are $1 \mathrm{~mm} / \mathrm{s}, 50 \%$ of cake's height, and $5 \mathrm{~s}$.

\subsubsection{Sensory evaluation of cakes}

The scoring sensory tests were performed by semi-trained 10 panelists in Food Engineering Department, Ege University, Izmir. The sensory test included the attributes as color, aroma, flavor, firmness and overall acceptability which were to rate on a five-point hedonic scale from 1 to 5 with 1 being poor and 5 being excellent. The panelists were not informed by the amount of addition of fruit powder to the cake formulation prior to sensory evaluation.

The data was analyzed (analysis of variance (ANOVA) at $\mathrm{P}<0.05$ ) by using statistical software SPSS 16.0 (SPSS Inc., Chicago, IL, USA). The baking of cakes was replicated twice and all the analyses were triplicated.

\section{Results and discussion}

\subsection{Analysis of raw materials and fruit powders}

Fruits should be added in a dry and stable form for convenience in order to be used in the dough preparation. Considering the difficulties (heterogeneous dispersion, deterioration in the cake structure, high moisture content, etc.) of the addition of fresh fruit slices or puree directly into the cake, the freezedrying method has been chosen in order to obtain fruit powder with the closest quality characteristics of the fresh fruit. Considering dosage and mixing applications, it is more advantageous to use the fruits in dried powder form for bakery products. In the selection of the drying method, it was considered that the product will be exposed to high temperatures during baking. For this purpose, the freezedrying method which results in the highest quality of dried material was chosen. MC, $\mathbf{a}_{w}$, and color values of the fresh fruits and fruit powders are shown in Table 1.

In the previous studies, there are numerous of articles concluding the advantages of the freeze-drying process where the heat-sensitive nutrients in the food products are better protected due to the low temperatures during drying. It was reported by Krokida and Philippopoulos [13], that some volatile compounds are lost in the early stages of freeze-drying due to their higher vapor pressure than ice, but in later stages, the dried porous layer acts as a barrier to the loss of the valuable components.

Table 1. The MC, $\mathrm{a}_{\mathrm{w}}$, and color values of the fresh fruits and the fruit powders.

\begin{tabular}{|c|c|c|c|c|c|c|c|}
\hline \multicolumn{2}{|c|}{ Analysis } & Kiwi & Pumpkin & Quince & Kiwi Powder (KP) & Pumpkin Powder (PP) & Quince Powder (QP) \\
\hline \multicolumn{2}{|c|}{$\mathrm{MC}(\%)$} & $81.29 \pm 0.02^{\mathrm{a}}$ & $92.64 \pm 0.26^{c}$ & $83.72 \pm 0.39^{b}$ & $4.20 \pm 0.05^{\mathrm{a}}$ & $5.24 \pm 0.97 \mathrm{c}$ & $4.47 \pm 0.13^{\mathrm{b}}$ \\
\hline \multicolumn{2}{|c|}{$a_{w}$} & $0.98 \pm 0.05^{\mathrm{a}}$ & $0.98 \pm 0.03^{a}$ & $0.97 \pm 0.02^{\mathrm{a}}$ & $0.23 \pm 0.01^{\mathrm{a}}$ & $0.27 \pm 0.01^{b}$ & $0.24 \pm 0.01^{\mathrm{a}}$ \\
\hline \multirow{3}{*}{$\begin{array}{l}\text { Coluer } \\
\text { Values }\end{array}$} & $L^{*}$ & $47.37 \pm 0.35^{a}$ & $47.75 \pm 0.08^{\mathrm{a}}$ & $75.69 \pm 1.53^{\mathrm{b}}$ & $78.12 \pm 0.44^{c}$ & $74.83 \pm 1.78^{\mathrm{b}}$ & $69.74 \pm 1.14^{\mathrm{a}}$ \\
\hline & $a^{*}$ & $-0.67 \pm 0.24^{\mathrm{a}}$ & $12.17 \pm 0.33^{\mathrm{c}}$ & $1.32 \pm 0.22^{\mathrm{b}}$ & $-6.53 \pm 0.12^{\mathrm{a}}$ & $12.47 \pm 1.02^{\mathrm{c}}$ & $8.26 \pm 0.74 b$ \\
\hline & $b^{*}$ & $17.50 \pm 0.29^{a}$ & $31.31 \pm 0.45^{\mathrm{b}}$ & $35.25 \pm 0.99 c$ & $22.08 \pm 0.11^{\mathrm{a}}$ & $48.16 \pm 2.65^{c}$ & $23.59 \pm 1.14^{\mathrm{b}}$ \\
\hline
\end{tabular}

a-c: Indicate the significant differences between fresh fruits or fruit powders $(P<0.05)$. 
The highest moisture content values were obtained for fresh pumpkin and pumpkin powder whereas the lowest values were obtained for fresh kiwi and kiwi powder. Different chemical composition of the fruits is the reason for the different moisture content values. The $\mathrm{a}_{\mathrm{w}}$ values of fresh fruits were found to be higher than 0.98 and the freeze-drying process resulted in low $a_{w}$ values $(<0.3)$ which is important for safe storage. The highest $\mathrm{L}^{*}$ value was observed for fresh quince due to its light yellow color, however, the freeze-drying process resulted in lower $\mathrm{L}^{*}$ value compared to fresh quince. The oxidation and/or Maillard reactions during the preparation of quince puree with maltodextrin and drying process may be the reason for lower $\mathrm{L}^{*}$ value. The addition of maltodextrin may be the reason for higher $L^{*}$ values of kiwi and pumpkin powders compared to fresh material. Negative a*values were obtained for fresh kiwi and kiwi powder which indicate green color. Higher $b^{*}$ values were obtained for dried samples except for pumpkin powder.

\subsection{Analysis of batter and cake samples}

The results of the analysis of MC for the batter and the cakes with different amounts of fruit powders are given in Table 2 . MC values of plain batter and cake, and cake samples with different amounts of the fruit powders were found to be as $28.24 \%, 21.83 \%$, and $22.65-28.32 \%$, and $14.38-20.31 \%(\mathrm{wb}$ ), respectively. The highest MC value $(28.32 \%)$ was obtained from the batter containing 5\% quince powder and moisture contents of all batters decreased according to increasing the addition of fruit powder $(P<0.05)$. MC values of the plain batter was not significantly $(P>0.05)$ affected by the addition of fruit powder to the formulation in $5 \%$, on the other hand, the addition of fruit powder in 10\% significantly decreased MC of the batter and the cake around $7-15 \%$ and $15-25 \%$, respectively $(P<0.05)$. The increase in $10 \%$ to $20 \%$ resulted in a slight decrease in MC values of cakes containing kiwi and quince powders $(P>0.05)$. Since the wheat flour has a higher MC value $[10.88 \%(\mathrm{wb})]$ than the fruit powders $(4.20-5.24 \%)$ the replacement of the wheat flour with the fruit powders caused a significant decrease in MC value of both the batter and cake $(P<0.05)$. Similar findings were also obtained by Çalışkan Koç et al [14] reported that significantly higher $M C$ and $a_{w}$ values were obtained from the plain cake batters (MC:26.63-28.96\% and $\mathrm{a}_{\mathrm{w}}: 0.880-0.902$ ) and cakes (MC: $12.75-16.40 \%$ and $a_{w}: 0.722-0.768$ ) compared to the cake batters (MC:28.24\% and $a_{w}: 0.902$ ) and cakes with spinach powder (MC: $22.33 \%$ $a_{w}: 0.822$ ). The decrease in MC of the cake with fruit powders also leads to a decrease in the amount of water to be evaporated. Baking process caused around 24, 34, and 35\% moisture loss for the kiwi, pumpkin, and quince batter, respectively. Baik et al [15] reported that the initial MC values of the chocolate and the vanilla cake batters were measured between $32.50-37.50 \%(\mathrm{wb})$ and decreased to $19.90-23.73 \%$ (wb) at the end of the baking in the gas-fired and electric powered oven. The measured moisture loss during baking in this study was found to be similar but slightly lower than the study performed by Baik et al [15] which might be caused due to a different formulation of the cakes, cooking conditions, and water holding capacity of the fruit powders.

$\mathrm{a}_{\mathrm{w}}$ values of the plain batter and cake were found to be as 0.864 and 0.825 , respectively. aw values of the batter and the cake containing the different amount of fruit powder ranged between 0.844-0.898 and 0.745-0.875, respectively (Table 3). The cake containing $5 \%$ quince powder displayed higher aw value than the other cakes and the addition of fruit powders affected $\mathrm{a}_{\mathrm{w}}$ values of both the batter and the cake, significantly $(P<0.05)$. When the amount of fruit powders is increased, this resulted in a significant decrease in the $a_{w}$ values of the cake batter $(P<0.05)$. Similar results were obtained for the cake with different amounts (4-10\% by weight) of spinach powder [14]. Related with the moisture content values, the lowest $a_{w}$ value was observed from the cake which contained $20 \%$ pumpkin powder. This can be explained with the high amounts of water retained by the fiber existing in pumpkin. As indicated by Raghavendra et al [16] the physical, chemical and microstructural characteristics of a fiber determine how much water it can hold. The additional benefits of high fiber content can be listed as an increase in bulking, swelling and/or thickening properties.

Table 2. The MC values of the batter and cake containing different amounts of fruit powders (\%, wb).

\begin{tabular}{cccc}
\hline Sample & \multicolumn{3}{c}{ Amount of Powder (as \% of Total Weight) } \\
\hline & 5 & 10 & 20 \\
Batter with Kiwi Powder (BKP) & $27.82 \pm 0.85^{\mathrm{bA}}$ & $23.91 \pm 0.76^{\mathrm{aA}}$ & $23.85 \pm 0.68^{\mathrm{aB}}$ \\
Batter with Quince Powder (BQP) & $28.32 \pm 1.02^{\mathrm{cA}}$ & $25.50 \pm 0.35^{\mathrm{bB}}$ & $22.65 \pm 0.20^{\mathrm{aA}}$ \\
Batter with Pumpkin Powder (BPP) & $27.45 \pm 1.22^{\mathrm{bA}}$ & $26.26 \pm 0.61^{\mathrm{bC}}$ & $23.67 \pm 0.65^{\mathrm{aB}}$ \\
Cake with Kiwi Powder (CKP) & $20.31 \pm 1.65^{\mathrm{bC}}$ & $18.66 \pm 1.32^{\mathrm{aB}}$ & $18.27 \pm 0.13^{\mathrm{aC}}$ \\
Cake with Quince Powder (CQP) & $17.45 \pm 0.82^{\mathrm{bA}}$ & $16.28 \pm 0.17^{\mathrm{aA}}$ & $16.04 \pm 0.17^{\mathrm{aB}}$ \\
Cake with Pumpkin Powder (CPP) & $19.23 \pm 0.78^{\mathrm{cB}}$ & $16.77 \pm 0.46^{\mathrm{bA}}$ & $14.38 \pm 1.28^{\mathrm{aA}}$ \\
\hline
\end{tabular}

Data with different superscript letters in the same row (a-c, differences between the amount of powder) and column (A-C, differences between the cakes) indicate significant differences $(P<0.05)$.

Table 3. Water activity values of the batter and the cake which contain the different amount of fruit powders.

\begin{tabular}{cccc}
\hline Sample & \multicolumn{3}{c}{ Amount of Powder (as \% of Total Weight) } \\
\hline & 5 & 10 & 20 \\
BKP & $0.883 \pm 0.01^{\mathrm{cB}}$ & $0.878 \pm 0.00^{\mathrm{bC}}$ & $0.869 \pm 0.02^{\mathrm{aB}}$ \\
BQP & $0.898 \pm 0.05^{\mathrm{cC}}$ & $0.870 \pm 0.02^{\mathrm{bB}}$ & $0.866 \pm 0.02^{\mathrm{aB}}$ \\
BPP & $0.859 \pm 0.00^{\mathrm{cA}}$ & $0.851 \pm 0.01^{\mathrm{bA}}$ & $0.844 \pm 0.03^{\mathrm{aA}}$ \\
CKP & $0.830 \pm 0.04^{\mathrm{bA}}$ & $0.825 \pm 0.03^{\mathrm{bB}}$ & $0.745 \pm 0.00^{\mathrm{aA}}$ \\
CQP & $0.875 \pm 0.06^{\mathrm{cC}}$ & $0.831 \pm 0.02^{\mathrm{bC}}$ & $0.792 \pm 0.02^{\mathrm{aC}}$ \\
CPP & $0.865 \pm 0.03^{\mathrm{cB}}$ & $0.795 \pm 0.01^{\mathrm{bA}}$ & $0.753 \pm 0.00^{\mathrm{aB}}$ \\
\hline
\end{tabular}

Data with different superscript letters in the same row (a-c, differences between the amount of powder) and column (A-C, differences between the cakes) indicate significant differences $(P<0.05)$. 
The color values of batter and crumb of cake samples are shown in Figure 1 and 2, respectively. According to the results, it can be stated that there were significant differences between the color values of crust and crumb of plain and fruit powder fortified cakes $(P<0.05)$. When fruit powders were added to the cake formulation a significant difference in the color values of the cakes $(P<0.05)$ were observed. The addition of different amount of fruit powders generally resulted in insignificant changes in the crust color ( $\mathrm{L}^{*}$ and $\left.\mathrm{a}^{*}\right)$ of the cakes $(P>0.05$, Data was not given.), however, significant changes were observed in the $\mathrm{b}^{*}$ values (CKP:17.08-27.89, CQP:13.6-16.87, CPP:14.4$26.54, P<0.05)$. The lightness value of the kiwi powder was found to be higher than the other fruit powders (Table 1). For this reason, the cake with kiwi powder showed the lightest crust color (CKP:41.90-45.98, CQP:40.06-41.62, CPP:43.0348.22) The higher $a^{*}$ values were observed for the crust of the cake with pumpkin powder (13.78-16.91), whereas the lowest values were observed for cake with quince powder (12.3614.04). The freeze-dried pumpkin powder has the highest $\mathrm{a}^{*}$ and $\mathrm{b}^{*}$ values (Table 1 ).

Related to this result, the $a^{*}$ and $b^{*}$ values of the batter and the cake containing pumpkin powder were found to be higher than the other batter and cakes. A decrease in $L^{*}$ was observed with the addition of fruit powders and similar results were expressed by Ayadi et al [1] who investigated the effects of cladodes powders $(5,10,15$, and $20 \%)$ on the dough characteristics and functional properties. The researchers reported that the decrease of $L^{*}$ value of the cakes is mainly due to the existence of the reactions as Maillard and caramelization.

The weight loss is one of the main parameters which indicate the cooking quality [17]. It shows the removal of moisture which is effective on the physical properties and texture of the cakes from the dough during the baking process and changed between 3.8 and $7.6 \%$ (Figure 3 ) for the cakes containing fruits powder. The weight loss of the control cake was found to be higher than the other cakes. It might be due to the higher MC value of control cake batter or water holding capacity of fruit powders. In addition, since the solid content of cake formulations increased by the addition of fruit powders the amount of evaporated water decreased. These results were also in line with those obtained by Çalışkan Koç et al [14] and Aydogdu et al [18]. Aydogdu et al [18] reported that a higher amount of lemon fiber prevented the moisture loss of cakes compared to control because of its high water-binding capacity.

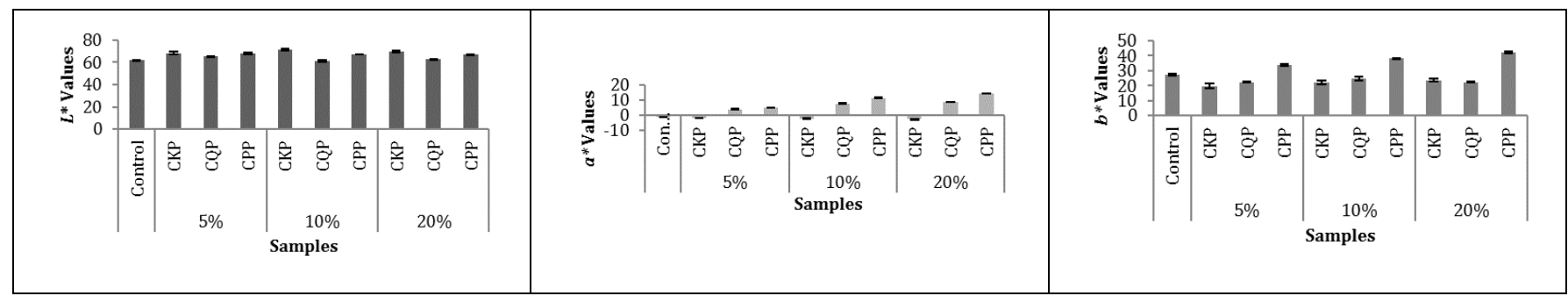

(a)

(b)

(c)

Figure 1(a),(b): and (c): The measured values of $\left(L^{*}, a^{*}\right.$, and $\left.b^{*}\right)$ the batters that containing different amounts of fruit powder.

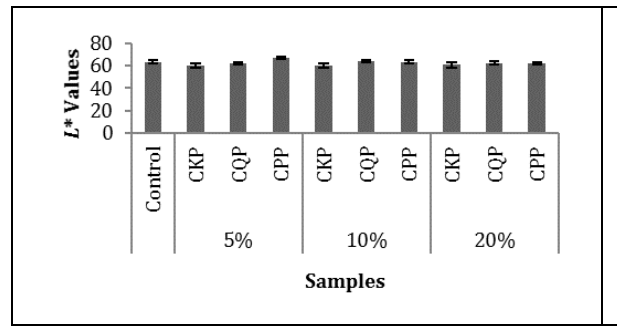

(a)

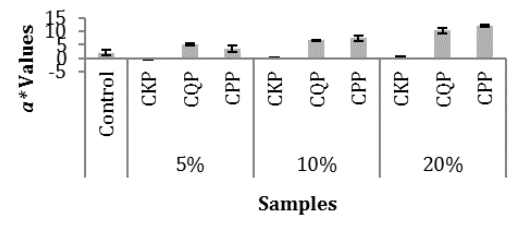

(b)

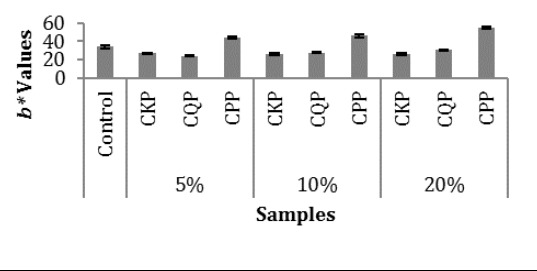

(c)

Figure 2(a),(b): and (c) The measured values of $\left(L^{*}, a^{*}\right.$ and $\left.b^{*}\right)$ inside surface of the cakes that containing fruit puree powder.

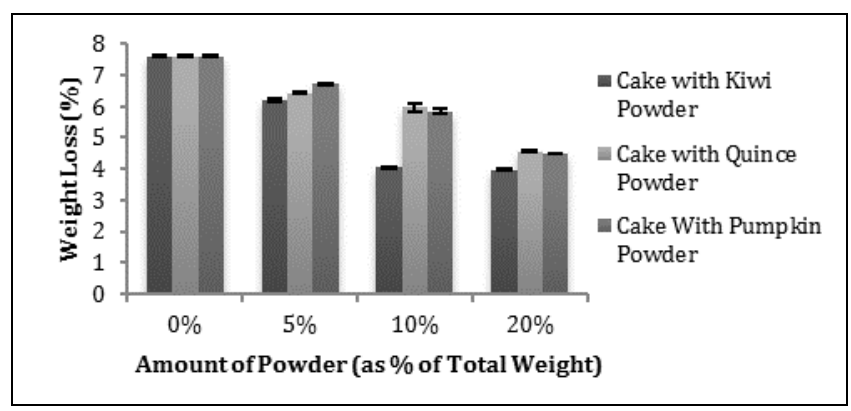

Figure 3. The weight loss values of fruit powder fortified cakes $(\%)$.
The VI, SI, and UI values of the cakes are given in Table 4. The highest VI value was observed for the control cake. In general, the cakes with low volume show low SI values. The increase in the amount of fruit powders resulted in a significant decrease in the VI values. Among the fruit cakes, the highest volume was observed as $92.78 \mathrm{~mm}$ in the cake containing $5 \%$ quince powder. That means that the cake had a desired convex shape. Similar VI values as between 86.00 and $98.00 \mathrm{~mm}$ were found by Seyhun et al [21] and the results were consistent with Hera et al [20]. However, Gomez et al [19] observed that the VI values of the cake samples were $127.40-171.10 \mathrm{~mm}$. The expected behavior of the cakes is the rise in the central part which is determined with a high SI. 
Table 4. volume (VI), symmetry (SI), and uniformity (UI) indexes (mm) values of the cakes.

\begin{tabular}{|c|c|c|c|}
\hline $\begin{array}{c}\text { Cake } \\
\text { Sample } \\
\end{array}$ & Volume Index (VI) & Symmetry Index (SI) & Uniformity Index (UI) \\
\hline Control Cake & $93.20 \pm 0.01^{\mathrm{e}}$ & $6.31 \pm 0.02^{\mathrm{c}}$ & $0.01 \pm 0.00^{\mathrm{a}}$ \\
\hline Cake with 5\% KP & $90.12 \pm 1.07 \mathrm{c}$ & $4.88 \pm 0.01^{b}$ & $0.01 \pm 0.00^{\mathrm{a}}$ \\
\hline Cake with $10 \% \mathrm{KP}$ & $88.81 \pm 0.01^{b}$ & $3.49 \pm 0.12^{\mathrm{a}}$ & $0.01 \pm 0.00^{\mathrm{a}}$ \\
\hline Cake with $20 \% \mathrm{KP}$ & $86.24 \pm 1.06^{a}$ & $3.65 \pm 0.03^{\mathrm{a}}$ & $0.00 \pm 0.00^{\mathrm{a}}$ \\
\hline Cake with 5\% QP & $92.78 \pm 0.05^{\mathrm{d}}$ & $6.45 \pm 0.05^{c}$ & $0.00 \pm 0.00^{\mathrm{a}}$ \\
\hline Cake with10\% QP & $91.25 \pm 0.96^{\mathrm{cd}}$ & $7.00 \pm 0.58^{d}$ & $0.02 \pm 0.00^{\mathrm{a}}$ \\
\hline Cake with $20 \%$ QP & $90.56 \pm 1.03^{c}$ & $6.13 \pm 0.53^{c}$ & $0.02 \pm 0.00^{\mathrm{a}}$ \\
\hline Cake with 5\% PP & $91.36 \pm 0.05^{d}$ & $4.78 \pm 0.09 \mathrm{~b}$ & $0.01 \pm 0.00^{\mathrm{a}}$ \\
\hline Cake with $10 \%$ PP & $88.50 \pm 1.29 b$ & $4.50 \pm 0.91^{b}$ & $0.01 \pm 0.00^{\mathrm{a}}$ \\
\hline Cake with $20 \%$ PP & $87.53 \pm 1.04^{\mathrm{ab}}$ & $4.12 \pm 0.74 \mathrm{~b}$ & $0.02 \pm 0.00^{\mathrm{a}}$ \\
\hline
\end{tabular}

Data with different superscript letters in the same column (a-e) indicate significant differences $(P<0.05)$.

In cases where the cake volume is not properly established and collapses at the end of the baking process, a negative SI will be observed. In fact, the SI defines the differences in height of the central and lateral parts of the cakes. The SI can also be used as a measure of gas retention in baked products [19]. Gomez et al [19] reported the SI values as -3.76 and $39.90 \mathrm{~mm}$ for the cakes. Other researchers observed SI values between -19.88 and 7.70 [20]. On the contrary of the quince and pumpkin cakes, the flatter surface of $\% 20$ kiwi cake caused the lowest symmetry index value. All the cakes showed the uniform structure and the differences in the UI values were found to be statistically insignificant $(P>0.05)$.

The vitamin $\mathrm{C}$ contents of the kiwi, quince, and pumpkin powders were found to be as $50.89,11.13$, and $19.18 \mathrm{mg} / 100 \mathrm{~g}$ (wb) fruit powder, respectively. The vitamin C content of the batter changed between 14.28-28.13\%, 9.30-11.69\% and 7.75$23.14 \%(\mathrm{wb})$ for the kiwi, quince, and pumpkin powder, respectively. A hight amount of vitamin $\mathrm{C}$ was not detectable in the plain batter and the batter with $5 \%$ quince powder. As it is expected, the vitamin $\mathrm{C}$ content of the batter significantly increased depending on the additional powder amount $(P<0.05)$. Vitamin C content ranged between for $15.94-32.94 \%$ the cake with kiwi powder, $6.17-15.73 \%$ for the cake with quince powder, and 12.24$23.28 \%(\mathrm{wb})$ for the cake with pumpkin powder. The kiwi powder with the highest vitamin $\mathrm{C}$ content caused the highest vitamin $\mathrm{C}$ content both in the batter and the cake. Considering the control cake where vitamin $\mathrm{C}$ amount was undetectable, vitamin $\mathrm{C}$ content of the cakes were improved with the addition of fruit powders. Similar results were also obtained by Çalışkan Koç et al [14] who reported that the vitamin C contents of the cakes were significantly increased depending on the addition of spinach powder $(P<0.05)$, however, the vitamin $C$ content of batter was not significantly affected from the amount of spinach $(P>0.05)$. Although the objectives of this study were to improve the formulation of the cakes and increasing the attractiveness of them for the consumers that seek healthier foods, an increase in the vitamin $\mathrm{C}$ content for a cooked material brings an important achievement. This also explains the use of the dried fruit powders for the improvement since vitamins are more stable and resistant to adverse effects in low moisture conditions.

\subsection{Hardness}

The effect of the different amounts of the additional fruit powders to the cake formulation on the hardness is given in Table 5. The hardness value of the control sample was measured as $376.62 \pm 34.72 \mathrm{~g}$. The hardness values of cake with $5 \%$ pumpkin powder and $20 \%$ kiwi and quince powders were found to be higher compared to control. The hardness values of cakes indicated that the cakes occurred significantly harder with the increasing amounts of the kiwi and quince powders and the decreasing levels of the pumpkin powder $(P<0.05)$. Similarly, Kim et al [22] indicated that as the addition increased, the cake samples became harder. Aydogdu et al [18] reported that the hardness values of cakes ranged between $1.31-3.82 \mathrm{~N}$ depending on the type (pea, oat, lemon, and apple) and amount (5 and 10\%) of fibers. In addition, the hardness values significantly affected by the and amount of fibers and this value was increased depending on the amount of fiber $(P<0.05)$. Barak et al [23] reported that an increase in the water absorption capacity of the flour which resulted in stiffness of dough that resulted in harder cookies. Similarly, in this study, the water-binding capacity of the cakes may be increased due to higher water-binding capacity of the fruit powders compared to wheat flour which may be resulted in higher hardness values.

\subsection{Sensory analysis}

The sensory analysis is an important tool for food processing companies for development and new product formulations regarding the marketing and acceptance of consumers. At the same time, sensory analysis is becoming one of the quality control attributes of food formulations [24]. The results of the sensory evaluation tests for cakes are presented in Table 6 . According to Table 6 , it can be said that the cake with $5 \%$ pumpkin powder had the highest score for color (4.26), flavor (4.19) and overall acceptability (4.63). The cake with $20 \%$ kiwi powder received the highest score for aroma (3.45). The score of sensory evaluations showed that increasing the amount of the fruit powder addition to the cake formulation caused a significant increase in the aroma $(P<0.05)$ and a significant decrease in color and overall acceptance $(P<0.05)$. The sensory evaluation is founded on the determination of the cake quality and general consumer acceptability showed that the cake containing pumpkin powder had greater acceptance by panelists and sensory properties of the cake were found to be greater than the other cakes $(P<0.05)$. The control cake with the high score of color (4.0), flavor (4.0), and overall acceptability (4.5) followed the cake with $5 \%$ pumpkin powder. Therefore, the differences between the score of the control cake and the cake with $5 \%$ pumpkin powder were not statistically different $(P>0.05)$. Similar to our results, Park et al [25] reported that replacement of wheat flour with turmeric powder (up to 6\%) in the cake formulations gives satisfactory overall acceptability 
Table 5. The results of the hardness ( $\mathrm{g}$ ) for the cakes with different amounts of kiwi, quince, and pumpkin powders.

\begin{tabular}{cccc}
\hline Sample & \multicolumn{3}{c}{ Amount of Powder (as \% of Total Weight) } \\
\hline & 5 & 10 & 20 \\
CKP & $146.56 \pm 17.54^{\mathrm{aA}}$ & $330.99 \pm 3.17^{\mathrm{bB}}$ & $864.22 \pm 28.81^{\mathrm{cC}}$ \\
CQP & $316.85 \pm 25.38^{\mathrm{bB}}$ & $251.08 \pm 14.96^{\mathrm{aA}}$ & $456.98 \pm 17.82^{\mathrm{cB}}$ \\
CPP & $410.90 \pm 25.89^{\mathrm{cC}}$ & $340.95 \pm 23.26^{\mathrm{bB}}$ & $103.15 \pm 0.01^{\mathrm{aA}}$ \\
\hline
\end{tabular}

Data with different superscript letters in the same row (a-c, differences between the amount of powder) and column (A-C, differences between the cakes) indicate significan differences $(P<0.05)$.

Table 6. The sensory ratings for the cakes with different amounts of kiwi, quince, and pumpkin powders.

\begin{tabular}{|c|c|c|c|c|c|c|c|c|c|}
\hline \multirow{3}{*}{$\begin{array}{c}\text { Quality } \\
\text { Characteristics }\end{array}$} & \multirow{2}{*}{\multicolumn{3}{|c|}{$\begin{array}{l}\text { Amount of Kiwi Powder (as \% of Total } \\
\text { Weight) }\end{array}$}} & \multirow{2}{*}{\multicolumn{3}{|c|}{$\begin{array}{l}\text { Amount of Quince Powder (as \% of Total } \\
\text { Weight) }\end{array}$}} & \multirow{2}{*}{\multicolumn{3}{|c|}{$\begin{array}{l}\text { Amount of Pumpkin Powder (as \% of Total } \\
\text { Weight) }\end{array}$}} \\
\hline & & & & & & & & & \\
\hline & 5 & 10 & 20 & 5 & 10 & 20 & 5 & 10 & 20 \\
\hline Color & $3.56 \pm 0.92^{\mathrm{cA}}$ & $3.00 \pm 0.25^{\mathrm{bA}}$ & $2.83 \pm 0.20 \mathrm{aA}$ & $3.65 \pm 0.92^{\mathrm{bA}}$ & $3.00 \pm 0.23^{\mathrm{aA}}$ & $2.86 \pm 0.22^{\mathrm{aA}}$ & $4.26 \pm 0.42^{\mathrm{bB}}$ & $4.01 \pm 0.30^{\mathrm{bB}}$ & $3.56 \pm 0.45^{\mathrm{aB}}$ \\
\hline Aroma & $2.50 \pm 0.09 \mathrm{aB}$ & $3.00 \pm 0.29 \mathrm{bB}$ & $3.45 \pm 0.25^{\mathrm{cB}}$ & $2.13 \pm 0.12^{\mathrm{aA}}$ & $3.00 \pm 0.25^{\mathrm{bB}}$ & $3.26 \pm 0.26^{\mathrm{bB}}$ & $2.20 \pm 0.12^{\mathrm{aA}}$ & $2.50 \pm 0.12^{\mathrm{bA}}$ & $2.70 \pm 0.23^{\mathrm{bA}}$ \\
\hline Flavor & $3.90 \pm 0.72^{\mathrm{bA}}$ & $2.65 \pm 0.18^{\mathrm{aA}}$ & $2.65 \pm 0.10^{\mathrm{aA}}$ & $3.87 \pm 0.82^{\mathrm{bA}}$ & $3.50 \pm 0.28^{\mathrm{bB}}$ & $3.10 \pm 0.10^{\mathrm{aB}}$ & $4.19 \pm 0.36^{\mathrm{bB}}$ & $4.01 \pm 0.32^{\mathrm{abC}}$ & $3.87 \pm 0.44^{\mathrm{aC}}$ \\
\hline Hardness & $3.65 \pm 0.75^{\mathrm{aC}}$ & $3.80 \pm 0.22^{\mathrm{aC}}$ & $3.85 \pm 1.09 \mathrm{aC}$ & $2.09 \pm 0.08^{\mathrm{aB}}$ & $2.50 \pm 0.06^{\mathrm{bB}}$ & $2.90 \pm 0.15^{\mathrm{cB}}$ & $1.78 \pm 0.06^{\mathrm{aA}}$ & $2.04 \pm 0.05^{\mathrm{bA}}$ & $2.26 \pm 0.20^{\mathrm{cA}}$ \\
\hline $\begin{array}{c}\text { Overall } \\
\text { Acceptability }\end{array}$ & $4.05 \pm 0.69 \mathrm{bA}$ & $3.00 \pm 0.27 \mathrm{aA}$ & $2.70 \pm 0.28^{\mathrm{aA}}$ & $4.10 \pm 0.29 \mathrm{cA}$ & $3.50 \pm 0.25^{\mathrm{bAB}}$ & $3.22 \pm 0.16^{\mathrm{aB}}$ & $4.63 \pm 0.16^{\mathrm{cAB}}$ & $4.06 \pm 0.27 \mathrm{bC}$ & $3.86 \pm 0.28^{\mathrm{aC}}$ \\
\hline
\end{tabular}

Data with different superscript letters in the same row (a-c, differences between the amount of powder) and column (A-C, differences between the cakes) indicate significant differences $(P<0.05)$.

\section{Conclusions}

The cakes with an alternative and improved formulation by the addition of fruit powders were obtained successfully. In addition, the addition of fruit powders in the cake formulation can prevent the addition of other synthetic color compounds such as green, yellow, orange, etc. Increasing the amount of the additional fruit powders caused a significant decrease in $M C$, $a_{w}$ brightness value, the volume and symmetry indexes, color and overall acceptance score of the cakes $(P<0.05)$. By adding fruit powder to the cake formulation resulted in an increase in vitamin $C$ value. Due to low MC and $a_{w}$ values, the shelf life of the cake can be increased by adding fruit powder to the cake formulation. The sensory evaluation showed that the cakes with different fruit powders and amounts have generally significantly different results $(P<0.05)$.

\section{Author contribution statements}

In the scope of this study, the contribution of Kadriye ERGÜN ALTAY and Gülşah ÇALIŞKAN KOÇ were in the literature survey, experimental study, the evaluation of the obtained results and the preparation of the article; the contribution of Safiye Nur DIRIM was to develop the experimental and evaluation strategies and the leadership in the preparation of the article.

\section{Ethics committee approval and conflict of interest statement}

"There is no need to obtain permission from the ethics committee for the article prepared". "There is no conflict of interest with any person/institution in the article prepared."

\section{References}

[1] Ayadi MA, Abdelmaksoud W, Ennouri M, Attia H. "Cladodes from Opuntiaficusindica as a source of dietary fiber: Effect on batter characteristics and cake making". Industrial Crops and Products, 30(1), 40-47, 2009.
[2] Lebesi DM, Tzia C. "Effect of the addition of different dietary fiber and edible cereal bran sources on the baking and sensory characteristics of cupcakes". Food and Bioprocess Technology, 4, 710-722, 2011.

[3] Ktenioudaki A, Gallagher E. "Recent advances in the development of high-fibre baked products". Trends in Food Science and Technology, 28, 4-14, 2012.

[4] Sudha L, Vetrimani R, Leelavathi K. "Influence of fibre from different cereals on the rheological characteristics of wheat flour batter and on biscuit quality". Food Chemistry, 100(4), 1365-1370, 2007.

[5] Seyhun N, Sumnu G, Şahin S. "Effects of different emulsifiers, gums and fat contents on retardation of staling of microwave baked cakes". Nahrung-Food, 47, 248-251, 2003.

[6] EscaladaPla MF, Ponce NM, Stortz CA, Gerschenson LN, Rojas AM. "Composition and functional properties of enriched fiber products obtained from pumpkin (Cucurbita moschata Duchesne ex Poiret)". LWT-Food Science and Technology, 40, 1176-1185, 2007.

[7] Caliskan G, Dirim SN. "The effects of the different drying conditions and the amounts of maltodextrin addition during spray drying of sumac extract". Food and Bioproducts Processing, 91, 539-548, 2013.

[8] Zea LP, Yusof YA, Aziz MG, Ling CN, Amin NAM. "Compressibility and dissolution characteristics of mixed fruit tablets made from guava and pitaya fruit powders". Powder Technology, 247, 112-119, 2013.

[9] Wang ZL, Finlay WH, Peppler MS, Sweeney LG. "Powder formation by atmospheric spray-freeze-drying". Powder Technology, 170, 45-52, 2006.

[10] Approved Methods of the American Association of Cereal Chemists. "American Association of Cereal Chemists (Method 10-91)". St. Paul, Minnesota, 10, 2000.

[11] Association of Official Analytical Chemists. "Official Methods of Analysis". Arlington, VA, 15, 1990. 
[12] Hışıl Y. The Analysis of Instrumental Food Analysis Laboratory. $6^{\text {th }}$ ed. Izmir, Turkey, Ege University Engineering Department Academic Press, 2007.

[13] Krokida MK, Philippopoulos C. "Rehydration of dehydrated foods". Drying Technology, 23, 799-830, 2005.

[14] Çalışkan Koç G, Erbakan T, Arıcı E, Dirim SN. "Sensory and quality attributes of cake supplemented with spinach powder". Gida, 44(5), 907-918, 2019.

[15] Baik OD, Marcotte M, Castaigne F. "Cake baking in tunnel type multi-zone industrial ovens part II. evaluation of quality parameters". Food Research International, 33, 599-607, 2000.

[16] Raghavendra SN, Rastogi NK, Raghavarao KSMS, Tharanathan RN. "Dietary fiber from coconut residue: effects of different treatments and particle size on the hydration properties". European Food Research and Technology, 218, 563-567, 2004.

[17] Kahraman K, Sakıyan O, Ozturk S, Koksel H, Sumnu G, Dubat A. "Utilization of mixolab to predict the suitability of flours in terms of cake quality". European Food Research and Technology, 227, 565-570, 2008.

[18] Aydogdu A, Sumnu G, Sahin S. "Effects of addition of different fibers on rheological characteristics of cake batter and quality of cakes". Journal of Food Science and Technology, 55(2), 667-677, 2018.
[19] Gómez M, Oliete B, Rosell CM, Pando V, Fernández E. "Studies on cake quality made of wheat-chickpea flour blends". LWT-Food Science and Technology, 41, 1701-1709, 2008.

[20] Hera E, Ruiz-París E, Oliete B, Gómez M. "Studies of the quality of cakes made with wheat-lentil composite flours". LWT-Food Science and Technology, 49, 48-54, 2012.

[21] Seyhun N, Sumnu G, Şahin S. "Effects of different starch types on retardation of staling of microwave-baked cakes". Food and Bioproducts Processing, 83, 1-5, 2005.

[22] Kim JH, Lee HJ, Lee HS, Lim EJ, Imm JY, Suh HJ. "Physical and sensory characteristics of fibre-enriched sponge cakes made with Opuntia humifusa". LWT-Food Science and Technology, 47, 478-484, 2012.

[23] Barak S, Mudgil D, Khatkar BS. "Effect of flour particle size and damaged starch on the quality of cookies". Journal of Food Science and Technology, 2014(51), 1342-1348.

[24] Rakcejeva T, Galoburda R, Cude L, Strautniece E. "Use of dried pumpkins in wheat bread production". Procedia Food Science, 1, 441-447, 2011.

[25] Park SH, Lim HS, Hwang SY. "Evaluation of antioxidant, rheological, physical and sensorial properties of wheat flour batter and cake containing turmeric powder". Food Science andTechnology International, 18(5), 435-443, 2012. 